picture of the formations from which this ornsmental species penetrated into gardens and parks all over the tropical world. The home of Poinciania regia, another ornamentel apecies encountered throughout the tropical world, is also mentioned.

In conclusion we may say that vol. 21 of Monographise Biologicae will serve as a valuable source of abundant details for any comparative work dealing with tropical environment and biota, and also as a fundamental introduction for present and future research workers on Madagascar. By far not only from the point of view of its size, the Great Island appears to be great, indeed!

\author{
JAN JENfK \\ Botanical Institute, \\ Czechoslovak Academy of Sciences, \\ 25243 Prühonice near Praha
}

Note

\title{
MYOOLOGIOAL NOMENCLATURE
}

Mycologists and lichenologists should note that a stending Nomenclature Committee has been established by the International Mycological Association to study apecific probleme in the applicstion of the Code of Nomenclature to fungi (including lichen-forming species), and to propose changes in the Code at the 1975 Botanical Congress. Actively interested persons are encouraged to serve on one or more Special Committees, each devoted to study of a specific problem. Five areas of concern have already been identified at the First International Mycological Congreas in Exeter in 1971; these Bpocial Committees are being organized now, and mycologists willing to serve on these Committees should notify the Nomenclature Secreteriat as soon as possible so that they may be appointed as members: (1) Revision of Art. 59 on pleomorphic fungi; (2) Designation of living materials as types in fungi; (3) Registry of new names and of proposals for conservation; (4) Unification of starting-point dates and problems of overlap of groups with different starting dates; (5) Provision for handling infraspecific taxa not now covered by the Code. Other problems that deserve study should be brought to the attention of the Secretariat, which may then establish additional Committees to study such problems.

Myoologists may correspond with any member of the Secretariat for further information, or to contribute opinions on any problems of nomenclature. Those desiring to propose their names for membership on Special Committees should notify the Chairman of the Secretariat.

I.M.A. Nomenclature Committee Secretariat:

R. P. KorF (Chairman), Plant Pathology Herbarium, Cornell University, Ithaca, N.Y. 14850, U.S.A.

D. L. Hawksworth, Commonwealth Mycological Ingtitute, Ferry Lane, Kew, Surrey TW9 3AF. England

G. L. Henn enserst, Lab. Mycologie Byst. et Appl., U.C.L., Parc d'Apenberg, B-3030 Heverlee, Belgium

Z. Pouzar, Botenical Institute, Czechoslovak Academy of Sciencés, 25243 Prủhonice near Prahs, Czachoslovakis

D. P. Rogkrs, Department of Botany, University of Illinois, Urbana, Illinoia 61801, U.S.A.

L. K. Weresub, Plant Research Institute, Central Experimental Farm, Ottawa, Ontario, Canada 